\title{
PEMIKIRAN PENDIDIKAN ISLAM PADA MASA NABI \& KHULAFAURRASYIDIN
}

\author{
Fadilatul Huda \\ Universitas Islam Negeri Sultan Syarif Kasim Riau \\ E-mail: Fadilatulhuda7@gmail.com \\ Yuliharti \\ Universitas Islam Negeri Sultan Syarif Kasim Riau \\ Yanti \\ Universitas Islam Negeri Sultan Syarif Kasim Riau
}

\begin{abstract}
The purpose of this paper is to examine more deeply the history of Islamic education before the time of Khulafaur Rashidin during the time of the Prophet Muhammad and the history of Islamic education during the time of Khulafaur Rashidin. This study is a data collection using library research with analytical techniques. The author will analyze his thoughts on education so that reforms can be taken that should be applied to the world of Islamic education in Indonesia for now. So that the system, objectives, curriculum, methods and content of Islamic education materials can be innovated in a sustainable manner according to the times. The results of this study indicate that Islamic education at the time of the Prophet was carried out in two periods, namely the Mecca and Medina periods. The Mecca period education was carried out in three stages, namely the clandestine stage, the overt stage and the general appeal stage. While the education of the Medina period was a continuation of education in Mecca, namely the formation and development of a new society, towards a social and political unity, socio-political and civic education as well as children's education. After the death of the Prophet Muhammad, Islamic education was continued by Khulafaur Rashidin. Islamic education at this time was divided into four periods, namely: the period of Caliph Abu Bakr as-Siddiq, the period of Caliph Umar bin Khatab, the period of Caliph Usman bin Affan and the period of Ali bin Abu Talib.
\end{abstract}

\begin{abstract}
Abstrak
Tujuan penulisan ini adalah untuk mengkaji lebih dalam mengenai sejarah pendidikan Islam sebelum masa Khulafaur Rasyidinpada masa Nabi Muhammad SAW dan sejarah pendidikan Islam pada masa Khulafaur Rasyidin. Penelitian ini merupakan pengumpulan data menggunakan penelitian kepustakaan dengan teknik analisis. Penulis akan menganalisis pemikirannya terhadap pendidikan agar dapat diambil pembaharuannya yang patut diaplikasikan bagi dunia pendidikan Islam di Indonesia untuk saat ini. Sehingga sistem, tujuan, kurikulum, metode serta muatan materi pendidikan Islam dapat diinovasi secara berkelanjutan sesuai perkembangan zaman. Hasil penelitian ini menunjukkan bahwa Pendidikan Islam pada masa Rasulullah dilaksanakan dalam dua periode, yaitu periode
\end{abstract}


Mekah dan Madinah. Pendidikan periode Mekah dilakukan dengan tigatahapan, yaitu tahapan sembunyi-sembunyi,tahapan secara terang-terangandan tahapan seruan umum. Sedangkan pendidikanperiode Madinah merupakan kelanjutan pendidikan di Mekah, yaitu pembentukan dan pembinaan masyarakat baru, menuju satu kesatuan sosial dan politik, pendidikan sosialpolitik dan kewarganegaraan serta pendidikan anak. Setelah meninggalnya Rasulullah SAW, pendidikan Islam dilanjutkan oleh Khulafaur Rasyidin. Pendidikan Islam pada masa ini dibagi menjadi empat periode, yaitu: periode Khalifah Abu Bakar as-Siddiq, periodeKhalifah Umar bin Khatab, periode Khalifah Usman bin Affan dan periode Ali bin Abu Thalib.

Kata Kunci: Pendidikan Islam, Periode Mekkah, Periode Madinah, Periode Khulafaur Rasyidin

\section{Pendahuluan}

Pendidikan agama Islam telah berlangsung sejak beribu-ribu tahun yanglewat, para ilmuan-ilmuan juga bermunculan dengan berbagai hasil karangannnya, baik dalam bidang pikih, hadis, tafsir, kedokteran, filsafat, dan lain sebagainya,namun sejak Hulagu Khan menyerang Baghdad, pendidikan Islam mengalami kemunduran, para ilmuan tidak lagi diperdapati layaknya Islam dimasa kejayaan,keadaan ini berlangsung cukup lama, namun umat Islam berhasil bangkit dariketerpurukan tersebut dengan mengadakan berbagai pembaharuan, seperti pembaharuan dalam pendidikan.

Pendidikan Islam sebagai suatu sub sistem dari sistem pendidikan pada umumnya dan baru dikenal sesudah diutusnya Muhammad saw. Sistem pendidikan Islam mengacu kepada nilai-nilai Islam. Oleh karena itu, sistem pendidikan Islam menciptakan perbedaan yang mendasar dengan sistem pendidikan pada umumnya (modern) baik dari Timur maupun dari Barat. Perbedaan yang menonjol antara keduanya terletak pada sikap atau pandangan terhadap hidup itu sendiri, dimana Islam menganggap hidup bukan suatu akhir dari segalanya tetapi alasan untuk mencapai tujuan-tujuan spritual setelah hidup. Sedangkan dalam pandangan Barat, kenikmatan menjadi tujuan akhir hidup yang didukung oleh materi yang berkecukupan (Suwito dan Fauzan, 2008). Pendidikan islam diharapakan dapat menghasilkan manusia yang berguna bagi dirinya dan masyarakat sekitarnya serta gemar mengamalkan dan mengembangkan ajaraan islam dalam berhubungan dengan Allah dan manusia sesamanya.

Walaupun pendidikan Islam memiliki sejarah yang panjang mulai dari zaman Nabi Muhammad sampai saat ini, namun tulisan ini dibatasai pada proses pendidikan Islam masa Rasulullah saw. Adapun garis besar permasalahan dalam tulisan ini:

1. Bagaimana sistem pendidikan Islam pada masa Rasulullah saw

2. Bagaimana sistem pendidikan Islam pada masa Khulafaurrasyidin 


\section{Metode}

Pengumpulan data penelitian ini menggunakan penelitian kepustakaan dengan teknik analisis. Penulis akan menganalisis pemikirannya terhadap pendidikan agar dapat diambil pembaharuannya yang patut diaplikasikan bagi dunia pendidikan Islam di Indonesia untuk saat ini. Sehingga sistem, tujuan, kurikulum, metode serta muatan materi pendidikan Islam dapat diinovasi secara berkelanjutan sesuai perkembangan zaman.

\section{Hasil dan Pembahasan}

\section{Pendidikan Islam Pada Masa Rasulullah}

Ketika Nabi Muhammad saw lahir (570) masehi, Makkah adalah sebuah kotayang sangat penting dan terkenal diantara kota-kota di negeri Arab, baik karenatradisinya maupun karena letaknya. Kota ini dilalui jalur perdagangan yang ramai, menghubungkan Yaman di Selatan dan Suriyah Utara. Dengan adanya Kakbah ditengah kota Makkah, menjadi pusat keagamaan Arab. Adapun kelahiran nabiadalah sebagai rahmat bagi sekalian alam yang akan membuat perubahan besar didunia, baik untuk bangsa Arab atau bangsa lainnya. Rasulullah saw diangkat menjadi rasul pada tanggal 17, tahun $610 \mathrm{M}$ padausia 40 tahun. Wahyu yang pertama turun ialah Surah Al Alaq, kemudian surahalMuddatsir (74)

Pada zaman Rasulullah saw. Pendidikan Islam dilaksanakan pada dua periode, yaitu periode Makkah dan periode Madinah. Periode Makkah sebagai fase awal pembinaan pendidikan Islam dan berpusat di Makkah, sedangkan periode Madinah sebagai fase lanjutan pembinaan pendidikan Islam sekaligus sebagai pusat kegiatannya.

Pelaksanaan pendidikan Islam pada kedua periode tersebut diuraikan secara singkat sebagai berikut:

\section{Pendidikan Islam Periode Mekkah}

Kaum muslimin Mekkah pada saat itu diperlakukan dengan semena-menaditanah airnya sendiri layakya Muslim Rohigya di Myamar atau bahka lebih dariitu, mereka tidak mendapatkan kebebasan sebagaimana penduduk lainnya yang tidak beragama Islam. Banyak pembunuhan, penyiksaan dan penindasan yangterjadi pada kaum muslimin, hingga akhirnya rasulullah hijarah bersama pengikutnya ke Kota Madinah. Sesampainya rasul beserta pengikutnya ke Madinah, mereka disambut dengan sangat baik serta diiring-iringi dengan sholawat badar.

Pekerjaan pertama yang rasul lakukan setelah sampai di Madinah 
adalahmembangun masjid, salah satu dari ruangan Masjid itu beliau pergunakan secarakhusus untuk mengajar para sahabat. Ruangan itu dikenal dengan sebutan alSuffah yang juga berfungsi sebagai asrama bagi para siswa yang miskin. Selain Perguruan al-Suffah, di Madinah juga terdapat tempat pendidikan yang lain misalnya Dar al-Qurra, yang secara kebahasaan berarti rumah para pembaca Alquran yang awalnya merupakan rumah Malik Mukhramah bin Nufal. Nabi saw juga membuat pendidikan khusus kaum wanita, ia menentukan hari-hari khususuntuk mengajar para wanita karena mereka selama ini merasa di kalahkan oleh kaum pria.

Mesjid yang merupakan bangunan pertama yang di dirikan rasul, yang berfungsi sebagai lembaga pendidikan merupakan cerminan dari pemikiran beliauyang begitu luas, karena apabila ditelusuri, maka pendidikan merupakan salah satu cara yang paling efektif dalam menyebarkan agama.

Kegiatan lain yang rasul lakukan di Madinah antara lain : mempersaudarakan kaum Muhajirin dengan kaum Anshor berdasarkan agama sebagai basis warganegara, membuat batas wilayah sebagai basis toritorial dengan membuat parit pada waktu Perang Khandaq dan terakhir membuat lembaga-lembaga pelengkap sebuah pemerintahan seperti angkatan perang, pengadilan, lembaga pendidikan, baitul mal serta lembaga yang mengatur administrasi negara serta menyusun ahli-ahli yang cakap yang bertindak sebagai pendamping nabi.

Pendidikan Islam pada masa Rasulullah SAW di Mekkah dilakukan dalam tiga tahapan sebagai berikut:

a) Tahapan Sembunyi-sembunyi. mulanya beliau melakukannya penyiaran Islam secara diam-diam di lingkungan sendiri dan di kalangan rekan- rekannya. Karena itulah orang yang pertama kali menerima dakwahnya adalah keluarga dan sahabat dekatnya. (Ramayulis, 2012).

b) Tahapan Terang-terangan. Setelah tiga tahun dakwah Islam disampaikan secara sembunyi, turunlah perintah Allah SWT. agar Nabi melaksanakan dakwah secara terangterangan. Perintah ini didasarkan pada Q.S. Al-Hijr ayat 94 yang artinya: "Maka sampaikanlah olehmu secara terang-terangan segala apa yang diperintahkan (kepadamu) dan berpalinglah dari orang musyrik." kemudian dilanjutkan dengan firman Allah dalam Q.S. Asy-Syuara" ayat 214 yang artinya: "Dan peringatkanlah kepada sanak family dan keluargamu terdekat. "Perintah dakwah secara terang- terangan ini seiring dengan semakin bertambahnya jumlah sahabat Rasulullah dan untuk meningkatkan seruan dakwah (Abdul Kodir, 2015:41). 
c) Tahapan Seruan Umum. Rasulullah SAW. mengubah strategi dakwah dengan seruan umum, umat manusia secara keseluruhan. Hal ini dilakukan pada musim- musim haji ketika banyak kaum diluar Mekkah berdatangan untuk melaksanakan haji. Pada tahap ini, berkat semangat yang tinggi dari para sahabat dalam mendakwahkan ajaran Islam, seluruh penduduk Yatsrib masuk Islam, kecuali orang-orang Yahudi.

\section{Metode Pendidikan}

Adapun metode pendidikan Islam masa Rasulullah SAW di Mekkah sebagai berikut:

\section{a) Metode ceramah}

b) Dialog, misalnya dialog antara Rasulullah SAW. dan Mu"az ibn Jabal ketika Mu"az akan diutus sebagai kadi ke negeri Yaman, dialog antara Rasulullah SAW. dan para sahabat untuk mengatur strategi perang.

c) Diskusi atau tanya jawab, yaitu sahabat bertanya kepada Rasulullah tentang suatu hukum, kemudia Rasulullah SAW. menjawabnya.

d) Metode perumpamaan, misalnya perumpamaan yang di ucapkan oleh Rasulullah SAW. bahwa orang mukmin itu laksana satu tubuh, apabila sakit salah satu anggota tubuh, anggota tubuh yang lainnya turut merasakannya.

e) Metode kisah, misalnya kisah beliau SAW. dalam isra dan mi"raj.

f) Metode pembiasaan, membiasakan kaum Muslim shalat berjamaah dan ibadah- ibadah lainnya yang dianjurkan dalam Al-Qur"an dan hadis.

g) Metode hafalan, misalnya para sahabat dianjurkan untuk menjaga Al-Qur"an dengan menghafalnya (Abdul Kodir, 2015).

\section{Kurikulum Pendidikan}

Kurikulum pendidikan Islam pada periode Rasulullah SAW di Mekkah adalah AlQur"an, yang Allah SWT. Wahyukan sesuai dengan kondisi dan situasi, kejadian dan peristiwa yang dialami umat Islam pada saat itu. Oleh sebab itu, dalam praktiknya kurikulum tersebut tidak hanya logis dan rasional, tetapi juga secara fitrah dan pragmatis. Pada fase Mekkah, materi pendidikan difokuskan pada hal-hal berikut, diantaranya: pertama, materi yang diajarkan hanya berkisar pada ayat-ayat Makiyyah sejumlah 93 surat pendek dan petunjuk Rasulullah SAW. yang dikenal dengan sunnah dan Hadis. Kedua, materi pengajarannya menitikberatkan pada keimanan, ibadah dan akhlak. 


\section{Materi Pendidikan}

a) Materi yang diajarkan hanya berkisar pada ayat-ayat Makiyyah sejumlah 93 surat dan petunjuk-petunjuknya yang dikenal dengan sebutan sunnah dan hadits.

b) Materi yang diajarkan menerangkan tentang kajian keagamaan yang menitikberatkan pada keimanan, ibadah dan akhlak.

\section{Pendidikan Islam Periode Madinah}

Pendidikan Islam Masa Rasulullah SAW di Madinah. Menurut Hanun Asrohah (1999), selama di Mekkah, Rasulullah SAW. dan para sahabat selalu mendapatkan tantangan dari kaum Quraisy yang selalu mengganggu dakwah Islam. Rasulullah SAW. Akhirnya hijrah ke Madinah (Yatsrib). Kedatangan Rasulullah SAW. bersama kaum Muslim Mekkah (Muhajirin) disambut oleh penduduk Madinah (Anshar) dengan gembira dan penuh dengan rasa persaudaraan karena telah banyak penduduk Madinah yang memeluk agama Islam. Islam mendapat lingkungan baru yang memungkinkan Rasulullah SAW untuk meneruskan dakwah menyampaikan ajaran Islam (Zuhairini dkk, 1995). Hijrah dari Mekkah ke Madinah bukan hanya sekedar berpindah dan menghindarkan diri dari tekanan dan ancaman kaum Quraisy, tetapi juga sebagai taktik dan strategi untuk mengatur dan menyusun kekuatan dalam menghadapi tantangan-tantangan lebih lanjut, sehingga akhirnya nanti terbentuklah masyarakat baru yang di dalamnya bersinar kembali mutiara tauhid warisan Nabi Ibrahim a.s. yang akan disempurnahkan oleh Nabi Muhammad SAW. melalui wahyu Allah SWT.

Lembaga Pendidikan, Metode, dan Materi Pendidikan Islam masa Rasulullah di Madinah masih sama seperti yang di terapkan di Mekkah. Adapun lembanga pendidikan di Madinah adalah Kuttab, Masjid, dan Suffah. Metode pendidikan Islam masa Rasulullah SAW. di Madinah, antara lain: pertama, dalam bidang keimanan, yaitu melalui tanya jawab dengan penghayatan yang mendalam dan di dukung oleh bukti-bukti yang rasional dan ilmiah. Kedua, materi ibadah yaitu disampaikan dengan metode demonstrasi dan peneladanan sehingga mudah didikuti masyarakat. Ketiga, bidang akhlak yaitu Nabi SAW. menitikberatkan pada metode peneladanan Nabi SAW.

\section{Metode Pendidikan}

a. Dalam bidang keimanan: melalui Tanya jawab dengan penghayatan yang mendalam dan di dukung oleh bukti-bukti yang rational dan ilmiah.

b. Materi ibadah: disampaikan dengan metode demonstrasi dan peneladanan sehingga mudah didikuti masyarakat. 
c. Bidang akhlak: Nabi menitikberatkan pada metode peneladanan. Nabi tampil dalam kehidupan sebagai orang yang memiliki kemuliaan dan keagungan baik dalam ucapan maupun perbuatan.

\section{Kurikulum Pendidikan}

a. Upaya pendidikan yang dilakukan Nabi pertama-tama membangun lembaga masjid, melalui masjid ini Nabi memberikan pendidikan Islam.

b. Materi pendidikan Islam yang diajarkan berkisar pada bidang keimanan, akhlak, ibadah, kesehatan jasmanai dan pengetahuan kemasyarakatan.

\section{Materi Pendidikan}

Materi pendidikan Islam sewaktu Nabi Muhammad SAW di Madinah adalah sebagai berikut:

1) Memperdalam dan memperluas materi yang pernah diajarkan di Mekkah seperti :

a) Hafalan dan penulisan dan Pengajaran Al-Qur"an masih berlangsung terus sampai dengan Rasulullah SAW. Bersama para sahabatnya hijrah ke Madinah.

b) Pemantapan ketauhidan umat Rasulullah SAW dalam bidang agama melakukan pembebasan dan sikap-sikap kemusyrikan, dengan pemahaman spiritualitas ajaran Islam.

c) Tulisan dan baca Al-Qur"an ketika Islam datang, pendidikan baca-tulis digalakkan dan dikembangkan.

d) Sastra Arab.

2) Pembentukan dan pembinaan masyarakat baru, menuju satu kesatuan sosial dan politik Nabi Muhammad SAW mulai meletakkan dasar-dasar terbentuknya masyarakat yang bersatu padu secara intern (ke dalam), dan ke luar diakui dan disegani oleh masyarakat lainnya (sebagai satu kesatuan politik).

3) Pendidikan sosial politik dan kewarganegaraan. Materi pendidikan sosial dan kewarnegaraan Islam pada masa itu adalah pokok- pokok pikiran yang terkandung dalam konstitusi Madinah, yang dalam prakteknya diperinci lebih lanjut dan di sempurnakan dengan ayat-ayat yang turun selama periode Madinah. Tujuan pembinaan adalah agar secara berangsur-angsur, pokok-pokok pikiran konstitusi Madinah diakui dan berlaku bukan hanya di Madinah saja, tetapi luas, baik dalam kehidupan bangsa Arab maupun 
dalam kehidupan bangsa-bangsa di seluruh dunia (Abdul Kodir, 2015).

4) Pendidikan anak. Dalam Islam, anak merupakan pewaris ajaran Islam yang dikembangkan oleh Nabi Muhammad saw dan gnerasi muda muslimlah yang akan melanjutkan misi menyampaikan Islam ke seluruh penjuru alam. Oleh karenanya banyak peringatan-peringatan dalam Alquran berkaitan dengan itu.

\section{Pendidikan Islam Pada Masa Khulafaur Rasyidin}

Khulafāur Rāsyidīn merupakan empat masa pemerintahan Islam setelah Nabi Muhammad shallallāhu 'alaihi wa sallam wafat. Setelah Nabi wafat, beberapa tokoh dari kaum Muhajirin dan Anshar berkumpul di balai kota Bani Sa"idah Madinah untuk bermusyawarah dalam memilih salah seorang tokoh yang akan menjadi pemimpin umat Islam. Dalam semangat ukhuwah slamiyah dan musyawarah berlandaskan dalil, Abu Bakar radhīyallāhu „anhu akhirnya terpilih dan dibai"at menjadi Khalifah pertama. Setelah Abu Bakar radhīyallāhu „anhu wafat, Umar bin Khattab radhīyallāhu „anhu melanjutkan kepemimpinan, dan kemudian dilanjutkan oleh Utsman Bin Affan radhīyallāhu ,anhu dan berikutnya oleh Ali bin Abi Thalib radhīyallāhu „anhu.

\section{Pendidikan Islam Periode Khalifah Abu Bakar As- Siddiq (11-13 H/632-634 M)}

Abu Bakar As-Siddiq radhīyallāhu „anhu dibaiat menjadi Khalifah pada tahun $11 \mathrm{H}$ atau $632 \mathrm{M}$. Beliau merupakan laki-laki dewasa yang paling awal membenarkan dan beriman kepada Ajaran Islam yang didakwahkan oleh Nabi Muhammad shallallāhu 'alaihi wa sallam. Beliau juga mengiringi Rasulullāh ketika berhijrah dari Mekkah ke Madinah (Al-Quraibi, 2009).

Pada masa kekhalifahan Abu Bakar dimulai dengan berbagai macam pergolakan di dalam lingkungan umat Islam berupa kerusakan-kerusakan oleh orang- orang murtad, orang-orang yang mengaku sebagai nabi dan orang-orang yang enggan membayar zakat. Berdasarkan kondisi tersebut, untuk mewujudkan keimanan dan kehidupan umat Islam yang stabil, maka Khalifah Abu Bakar melakukan tindakan tegas dengan memerangi para pemberontak dan perusak tersebut dan dikenal dengan Perang Riddah (Yatim, 2017). Penumpasan berhasil dilakukan dan kondisi internal umat kembali stabil, namun tidak sedikit umat Islam yang gugur, bahkan diantaranya terdapat sahabat dekat Rasulullāh dan para penghafal Al-Qur"an, sehingga mengurangi jumlah sahabat Rasulullāh yang hafal Al- Qur"an (Dalpen, 2016).

Pendidikan pada masa Khalifah Abu Bakar pada umumnya masih seperti pola pendidikan masa Nubuwah baik dari segi materi pendidikan maupun lembaga 
pendidikan. Menurut Prof. Mahmud Yunus di dalam buku Sejarah Pendidikan Islami, Materi pendidikan Islami yang diajarkan pada masa Khulafāur Rāsyidīn sebelum masa pemerintahan Umar bin Khatab, khususnya untuk pendidikan dasar adalah membaca dan menulis, membaca dan menghafal al Qur"an, serta mempelajari pokok-pokok ajaran Islam seperti cara wudhu, sholat, shaum dan sebagainya (Siti Zubaidah, 2016).

Pokok-pokok ajaran Islam yang diajarkan dapat dibagi dalam beberapa kategori materi pendidikan, yaitu:

a. Materi Pendidikan Tauhid, yang menurut Syaikh Utsaimin di dalam Syarhu Tsalatsatil Ushul, Tauhid adalah menjadikan Allāh sebagai satu- satunya sesembahan yang benar dengan segala kekhususannya.

b. Materi Pendidikan Akhlak, misalnya adab sehari-hari, adab kasih sayang, adab pergaulan, adab kehidupan ber masyarakat, berbangsa dan bernegara. Dalam Islam, Pendidikan Akhlak tidak dapat dipisahkan dengan Pendidikan Tauhid, bahkan Akhlak merupakan buah dari Tauhid.

c. Materi Pendidikan Ibadah, seperti wudhu", shalat, doa, dzikir, puasa, zakat dan haji. d. Materi Pendidikan Kesehatan yang terintegrasi pada bidang Tauhid, Akhlak, Ibadah, seperti tentang kebersihan tubuh dan lingkungan, adab makan dan minum, adab membuang air, adab mandi dan lain-lain (Dalpen, 2016).

Pusat pendidikan pada masa Khalifah Abu Bakar adalah di Madinah dan tenaga pendidiknya adalah para Sahabat Nabi .Selain keberadaan Masjid dan Shuffah sebagai tempat pendidikan yang telah ada sejak masa Nabi Muhammad, umat Islam mendirikan Kuttab sebagai tempat belajar membaca dan menulis, yang mendukung fungsi Masjid yang semakin kompleks. Masjid pada waktu itu berfungsi sebagai tempat shalat berjamaah, membaca dan mempelajari al- Qur"an, tempat mendiskusikan masalah berbagai masalah keumatan, tempat pertemuan dan lembaga pendidikan Islam.

\section{Pendidikan Islam Periode Khalifah Umar bin Khatab (13-23 H/634-644 M)}

Umar bin Khattab, nama lengkapnya adalah Umar bin Khattab bin Nufail keturunan Abdul Uzza Al-Quraisy dari suku Adi, salah satu suku yang terpandang mulia. Umar dilahirkan di Mekkah empat tahun sebelum kelahiran Nabi SAW. Umar masuk Islam pada tahun kelima setelah kenabian dan menjadi salah satu sahabat terdekat Nabi SAW serta dijadikan sebagai tempat rujukan oleh Nabi SAW mengenai hal-hal yang penting. Beliau dapat memecahkan masalah yang rumit tentang siapa yang berhak mengganti Rasulullah SAW. dalam memimpin umat setelah wafatnya Rasulullah SAW. Dengan 
memilih dan membai"at Abu Bakar sebagai Khalifah Rasulullah SAW. sehingga beliau mendapat penghormatan yang tinggi dan dimintai nasihatnya serta menjadi tangan kanan Khalifah yang baru itu. Sebelum meninggal dunia, Abu Bakar telah menunjuk Umar bin Khattab menjadi penerusnya.

Khalifah Umar bin Khatab radhīyallāhu „anhu berperan secara langsung sebagai pendidik dalam melakukan penyuluhan dan pembinaan Umat Islam di kota Madinah (Badwi \& Al- rasyidin, 2017). Penyelenggarakan kegiatan pendidikan diterapkan di masjid-masjid, tempat pendidikan (kuttab) dan pasar-pasar. Beliau juga memberikan instruksi kepada para panglima perang umat Islam untuk mendirikan masjid-masjid di setiap wilayah atau kota yang dikuasainya, yang berfungsi sebagai tempat ibadah dan juga sebagai tempat pendidikan. Pada periode ini diterapkan metode pendidikan, dimana siswa duduk melingkari gurunya di halaman masjid. Pola pendidikan untuk anak pada zaman Khalifah Umar mulai tertata, beliau membangun tempat khusus untuk menuntut ilmu bagi anak-anak di setiap sudut-sudut masjid (Nugraha, 2019). Penataan ini menginspirasi terbentuknya pendidikan anak saat ini lebih dikenal dengan berbagai istilah, seperti Taman Pendidikan al-Qur"an dan Taman Pendidikan Raudhatul Athfal. Berdasarkan hal tersebut, Khalifah Umar bin Khatab radhīyallāhu „anhu dapat dikatakan sebagai ,Bapak Ilmu Taman Kanak-Kanak' (Nugraha, 2019).

Untuk mendukung kegiatan pendidikan, Umar mengangkat dan menunjuk guruguru untuk tiap daerah yang ditaklukkan, yang bertugas mengajarkan isi Al- Qur"an dan ajaran Islam kepada penduduk yang baru masuk Islam karena negara Islam sudah menyebar luas keluar Jazirah Arabia, maka pusat pendidikan Islam bukan di Madinah saja, tetapi tersebar juga di kota-kota besar sebagai berikut: (a) Kota Mekkah dan Madinah (Hijaz), (b) Kota Basrah dan Kufah (Iraq), (c) Kota Damsyik dan Palestina (Syria), (d) Kota Fustat (Mesir).

Wilayah Kekhalifahan yang semakin luas mendorong pertumbuhan kegiatan pendidikan Islam. Semangat umat Islam, baik yang baru maupun yang sudah lebih dahulu menganut agama Islam, semakin besar untuk memperoleh ilmu ke-Islaman dari para sahabat Nabi, sehingga mobilitas para penuntut ilmu ke Madinah semakin lama semakin meningkat (Saufi \& Fadillah, 2015). Fenomena ini mulai melahirkan pembidangan disiplin ilmu keagamaan yang bermanfaat dalam perkembangan pendidikan bagi umat Islam yaitu pengajaran bahasa arab (Nugraha, 2019). Bidang pengajaran ini muncul karena orang yang baru masuk Islam dari daerah yang ditaklukkan harus belajar bahasa Arab, jika ingin belajar dan memahami pengetahuan Islam.

Oleh karena itu, pola dan perkembangan pendidikan pada masa Khalifah Umar bin Khatab lebih maju dibandingkan dengan masa sebelumnya (Nugraha, 2019; Saufi \& 
Fadillah, 2015). Mata pelajaran utama tetap sama yaitu membaca dan menulis Al Qur"an, menghafal dan menghayati kandungannya, Aqidah dan Ibadah serta pokok- pokok agama Islam. Untuk materi lainnya, berdasarkan arahan Khalifah Umar, yaitu mengajarkan anakanak berenang, memanah, seni mempertahankan diri, dan menunggang kuda.

\section{Pendidikan Islam Periode Khalifah Utsman bin Affan (23-35 H/644-656 M)}

Usman bin Affan, nama lengkapnya adalah Usman bin Affan bin Abil Ash bin Umayyah dari suku Quraisy. Beliau memeluk Islam karena ajakan Abu Bakar dan menjadi salah seorang sahabat dekat Nabi SAW. Usman ibn Affan terkenal sebagai orang yang berbudi pekerti luhur, sangat pemalu, dermawan, lemah lembut, penuh kasih sayang, pemaaf, selalu berprasangka baik, bersikap toleransi, paling baik bergaul dengan orang lain, lapang dada lagi sabar, paling kuat menjaga hubungan kekerabatan dan terlalu lemah serta tunduk kepada keluarga (Hitty, 1974). Beliau sangat kaya tetapi berlaku sederhana dan sebagian besar kekayaannya digunakan untuk kepentingan Islam.

Pendidikan Islam pada masa Khalifah Usman bin Affan, tidak jauh berbeda dengan masa-masa sebelumnya. Pendidikan pada masa ini hanya melanjutkan apa yang telah ada. Hanya sedikit perubahan yang mewarnai pelaksanaan pendidikan Islam dari apa yang telah ada. Para sahabat besar Rasulullah SAW., yang berpengaruh dan dekat dengan Rasulullah SAW., pada masa Khalifah Umar tidak diizinkan meninggalkan Madinah, maka pada masa Khalifah Usman diberikan sedikit kelonggaran untuk keluar Madinah dan menetap di daerah-daerah yang mereka sukai. Di daerah-daerah yang baru tersebut mereka mengajarkan ilmu-ilmu keislaman yang mereka miliki dan dapatkan langsung dari Rasulullah SAW.

Usaha yang kongkrit dalam bidang pendidikan Islam belum dikembangkan pada masa Khalifah Usman bin Affan. Khalifah sudah merasa puas terhadap pendidikan Islam yang telah berjalan pada masa-masa sebelumnya. Namun, yang penting untuk dicatat, suatu prestasi yang gemilang telah dicapai pada masa pemerintahan khalifah ketiga ini adalah usaha pembukuan kitab suci Al-Qur"an yang mempunyai pengaruh yang luar biasa bagi pendidikan Islam. Khalifah Usman melanjutkan usaha yang dulu dirintis oleh Khalifah Abu Bakar yaitu pengumpulan Al- Qur"an dari hafalan-hafalan para sahabat penghafal Al-Qur"an. Bundelan itu disimpan oleh Khalifah Abu Bakar, kemudian diserahkan kepada Khalifah kedua Umar bin Khattab, setelah itu dititipkan Khalifah Umar kepada puterinya Hafsah binti Umar yang juga istri Rasulullah SAW.

Enam tahun pertama kekhalifahan Usman bin Affan, pendidikan Islam mengalami perkembangan dan kemajuan yang pesat. Sedangkan pada enam tahun terakhir masa pemerintahan Khalifah Usman bin Affan pendidikan Islam tidak mengalami kemajuan 
yang berarti. Hal tersebut disebabkan oleh banyaknya persoalan- persoalan sosial politik yang pada akhirnya pemerintahan Khalifah Usman bin Affan mengalami kekacauan, baik di lingkungan keluarga maupun dilingkungan masyarakat. Masalah tersebut memicu terjadinya pemberontakan di berbagai kalangan masyarakat, akibat dari pemberontakan tersebut Khalifah Usman terbunuh.

Pendidikan Islam Periode Ali bin Abi Thalib (35-40 H/656-661 M)

Pengganti Khalifah Utsman radhīyallāhu „anhu adalah Ali bin Abi Thalib radhīyallāhu „anhu. Beliau merupakan orang yang pertama kali masuk Islam dari kalangan anak-anak atau remaja. Ibnu Hajar menyebutkan bahwa usia Ali ketika masuk Islam adalah 10 tahun. Ali bin Abi Thalib radhīyallāhu ,anhu merupakan putra dari paman Nabi Muhammad shallallāhu 'alaihi wa sallam yaitu Abu Tholib bin Abdul Muthalib dan juga merupakan suami dari putri Baginda Nabi, yaitu Fatimah Az Zahra radhīyallāhu „anha. Khalifah Ali adalah seorang perwira yang pemberani dan selalu menjadi pembela Nabi Muhammad shallallāhu 'alaihi wa sallam (Al-Quraibi, 2009).

Pada masa pemerintahan Khalifah Ali, terjadi banyak pergolakan, sehingga dapat dikatakan, hampir tidak pernah mengalami kedamaian. Pergolakan dan peperangan internal umat Islam terjadi secara bergantian, yang merupakan imbas dari fitnah dan syubhat serta kesalahpahaman. Pada saat itu, Khalifah Ali memiliki waktu untuk memikirkan permasalahan dalam sektor pendidikan, karena perhatiannya berfokus penuh pada permasalahan keamanan dan kedamaian ummat Islam, sehingga penyelenggaraan pendidikan Islam yang berlangsung tidak mengalami perbedaan dengan masa sebelumnya (Badwi \& Al-rasyidin, 2017). Materi pendidikannya mengalami sedikit perkembangan secara parsial dan tidak merata, tergantung kemampuan para gurunya dalam menjelaskan atau menangkal berbagai paham yang menyimpang pada waktu itu, sehingga memberikan dampak pada berkembangnya kajian-kajian hukum Islam .(Rama, 2016).

\section{Relevansi Pemikiran Pendidikan Islam Nabi Muhammad saw dan Khulafaurrasyidin dengan Pendidikan Islam Sekarang}

Dalam suatu proses pendidikan termasuk pendidikan Islam, faktor determinan adalah faktor pendidik dan peserta didik. Pendidik di masa Rasulullah saw adalah Nabi sendiri. Menjadi guru merupakan tugas yang diemban oleh Rasulullah saw. Sebagaimana diisyaratkan lewat firman-Nya Q.S. Ali Imran/3 : 164, Terjemahnya: Sungguh Allah telah memberi karunia kepada orang-orang yang beriman ketika Allah mengutus di antara mereka seorang rasul dari golongan mereka sendiri, yang membacakan kepada mereka ayat-ayat Allah, membersihkan (jiwa) mereka, dan mengajarkan kepada mereka al-Kitab dan al-Hikmah. Dan sesungguhnya sebelum (kedatangan Nabi) itu, mereka adalah benar- 
benar dalam kesesatan yang nyata.

Pada masa awal Islam nabi Muhammad saw sendiri yang menjadi guru. Beliaulah yang menyampaikan wahyu kepada sahabat-sahabatnya dan menjelaskan makna yang dikandung di dalamnya. Selanjutnya dibantu oleh sahabat-sahabatnya yang telah dikader dan dididik oleh beliau, termasuk isteri- isteri beliau sendiri. Khusus untuk pendidikan membaca dan menulis Nabi saw. memanfaatkan tenaga-tenaga non muslim, termasuk tawanan perang Badar.

Guru pada zaman ini tidak mengharapkan imbalan jasa, tetapi mereka mengajar untuk mencari keridhaan Allah swt. dan dengan tekad menyiarkan ajaran agama Islam. Rasulullah juga terkadang mengutus sahabat-sahabatnya untuk mengajarkan agama Islam di luar kota Madinah. Adapun yang menjadi peserta didik adalah sahabat- sahabat Nabi saw., dan ummat Islam pada umumnya, terutama orang-orang yang baru masuk Islam agar mereka dapat memahami ajaran Islam dengan baik dan mengamalkannya dalam kehidupannya sehari-hari.

Perkembangan pendidikan di Indonesia diwarnai oleh konsep pendidikan Islam, yang salah satu semangatnya berasal dari pola pendidikan yang berkembang pada masa Khulafāur Rāsyidīn. Ada beberapa implikasi dari konsep pendidikan Islam pada periode Khulafāur Rāsyidīn tersebut terhadap pengembangan pendidikan Islam di Indonesia.

Pertama, semestinya pengembangan kurikulum pendidikan Islam di Indonesia mempertahankan urutan yang dicontohkan yaitu selain memulai dengan membaca, menulis dan berhitung, juga sangat menekankan kepada pembentukan Aqidah Tauhid dan Akhlak. Mengutamakan akhlak dan adab sebelum mempelajari ilmu yang lain merupakan sebuah strategi utama dalam pendidikan Islam. Seiring dengan itu juga dilengkapi dengan pembiasaan Ibadah dan hidup sehat yang berbasis kepada adab dan akhlak. Kemudian dilanjutkan dengan bimbingan menghafal al-Quran secara bertahap yang strategi pengajarannya disesuaikan dengan potensi kecerdasan yang dimiliki setiap peserta didik. Pada tahap berikutnya, untuk mendukung persiapan kegiatan pendalaman materi, maka dilakukan pengajaran bahasa arab dan berbagai ilmu dasar lainnya yang dapat membantu dalam pembelajaran pada tahap selanjutnya

Kedua, melakukan penataan dan penguatan pendidikan anak usia pra sekolah dengan mengangkat guru-guru yang memiliki kualifikasi dan kompetensi yang tinggi, memberikan kesejahteraan yang sangat layak, dan mengembangkan sarana dan prasarana yang sesuai dengan prinsipprinsip pendidikan anak dalam Islam, yaitu mengembangkan kecerdasan dan kemampuan berdasarkan potensi atau kadar setiap anak.

Ketiga, pengembangan kurikulum pendidikan Islam juga harus memberikan perhatian yang besar terhadap pendidikan fisik diantaranya dengan mengadakan kegiatan latihan memanah, menunggang kuda dan latihan renang, serta seyogyanya pemerintah mengadakan perlombaanperlombaan yang menfasilitasi ketiga kegiatan pendidikan fisik tersebut. 
Keempat, sudah menjadi keharusan bagi pemerintah untuk memastikan bahwa guru-guru yang diangkat adalah guru yang memiliki adab dan akhlak yang mulia. Pemerintah juga memberikan perlindungan, perhatian dan bantuan agar para guru memiliki kesejahteraan yang sangat layak, serta memberikan fasilitas yang mempermudah para guru untuk meningkatkan kemampuan dalam menstransfer karakter dan ilmu.

Pengelola dan pengambil kebijakan pendidikan di Indonesia seharusnya berisikan para ahli pendidikan yang memahami karakter dan kebutuhan bangsa Indonesia khususnya umat Islam Indonesia, yang secara umum tidak bisa dipisahkan dengan pendidikan Islam yang merupakan pondasi utama umat Islam dalam mendidik karakter generasi berikutnya. Pemerintah seharusnya melakukan penguatan dan bantuan terhadap hal-hal yang masih kurang atau yang perlu ditingkatkan saja.

\section{Simpulan}

Berdasakan dari pemabahasan di atas dapat disimpulkan bahwa, Pendidikan Islam pada masa Rasulullah dilaksanakan dalam dua periode, yaitu periode Mekah dan Madinah. Setelah meninggalnya Rasulullah SAW, pendidikan Islam dilanjutkan oleh Khulafaur Rasyidin, Pendidikan Islam masa Khulafaur Rasyidin. Pendidikan Islam pada masa ini dibagi menjadi empat periode, yaitu: periode Khalifah Abu Bakar as-Siddiq, periode Khalifah Umar bin Khatab, periode Khalifah Usman bin Affan dan periode Ali bin Abu Thalib. Pendidikan Islam periode Abu Bakar sama dengan pelaksanaan pendidikan periode Rasulullah, baik dari segi materi dan lembaga pendidikannya.

\section{Referensi}

Al-Quraibi, I. 2009. Tarikh Khulafa (Faris Khairul Anam, Penerjemah). Qisthi Press.

Asrohan, Hanun. 1999. Sejarah Pendidikan Islam. Jakarta: Logos Wacana Ilmu.

Badwi, A., \& Al-rasyidin, K. 2017. Pendidikan Islam pada Periodeisasi Khulafaul Al- Rasyidin pada masa Nabi. Jurnal ASH- SHAHABAH: Jurnal Pendidikan Dan Studi Islam 3(2)

Dalpen, M. 2016. Sejarah Pendidikan Islam: Menelusuri Jejak Sejarah Pendidikan Era Rasulullah Sampai Indonesia. In Pola Pendidikan Islam pada Masa Khulafaur Rasyidin. Dalam S. Nizar (Ed.). Kencana Prenada Media Grup

Hitti, Philip K. 2001. Sejarah Ringkas Dunia Arab, terj. Usuluddin Hutagalung dan ODP Sihombing. Yogyakarta: Pustaka Iqra,

Kodir, Abdul. 2015. Sejarah Pendidikan Islam: Dari Masa Rasulullah hingga Reformasi di Indonesia. Bandung: Pustaka Setia.

Nugraha, M. T. 2019. Sejarah Pendidikan Islam: Memahami Kemajuan Peradaban 
Islam Klasik Hingga Modern. In Yogyakarta: Diandra. Diandra Kreatif.

Rama, B. 2016. Genealogi Ilmu Tarbiyah dan Pendidikan Islam: Studi Kritis terhadap Masa Pertumbuhan. Inspiratif Pendidikan, 5(2)

Ramayulis. 2012. Sejarah Pendidikan Islam; Napaktilas Perubahan Konsep, Filsafat dan Metodologi Pendidikan Islam dari Era Nabi SAW. Jakarta: Kalam Mulia.

Saufi, A., \& Fadillah, H. 2015. Sejarah Peradaban Islam. Grup Penerbitan CV Budi Utama.

Suwito \& Fauzan. 2008. Sejarah Sosial Pendidikan Islam Cet.II. Jakarta: Kencana Prenada Media Group

Yatim, B. 2017. Sejarah Peradaban Islam. Rajawali Press.

Zubaidah, Siti. 2016. Sejarah Peradaban Islam. Perdana Mulya Sarana Zuhairini, et.al. 1995. Sejarah Pendidikan Islam. Jakarta: Bumi Aksara, 1995. 